our Universities ought to be able to frame such a course, urges that a committee of teachers who have carefully considered the evidence here supplied should be able to draw up a practical scheme sufficiently definite, detailed, elastic, and progressive to secure its wide adoption. Unless this is done, a teacher's work cannot be measured, and he will get neither credit nor cash for it from his judges; and no amount of public opinion will really make such teaching general while this remains so. A good practical suggestion in accordance with these conclusions is that some experienced teacher should devote his power to the preparation of cheap leaflets, not stitched together, for a brief inductive course, from which each teacher might select a series according to his circumstances.

W. ODFLI

\section{THE WORK OF THE U.S. SIGNAL OFFICE UNDER GENERAL HAZEN}

$T H E$ recent cxamination by the joint commission of General IHazen and other witnesses, as to the efficiency and economy of the present administration of the Signal Office, is said to have brought out several statements as to the character of the work done by the Weathet Bureau, and the progress made by it during the last few years. The following is a brief summary of these, and especially of Prof. Abbe's statement showing the status and work being pursued during the present fiscal year :-

The Signal Scrvice employs I chief, I4 second lieutenants, and 500 enlisted men, of whom 150 are sergeants, 30 are corporals, and 220 are privates, but all generally known as Signal Service observers. These 515 persons constitute the Signal Corps proper: but 6 officers detailed from the line of the army are also temporarily attached to the service ; and these have control of the disbursements, the property, the weather-predictions, the display of signals, the testing and comparison of instruments, the arctic stations, the international bulletin, the monthly weather review, the Pacific Coast section, and other main divisions of work.

These 6 officers, by the operation of the present laws, are being diminished in number by 2 annually, their places being filled by promotions from among the sergeants of the corps; so that in a few years the service will employ only officers and men of the Signal Corps proper. This elimination of officers who have had from ten to twenty years' experience in the Signal Service and the army is somewhat deprecated by (ieneral Hazen, who is very naturally loath to lose their services, while they themselves are loath to go; although it is evident that the corps propcr already contains abundant and excellent material for the future needs of the service.

The Signal Service also employs a number of civilians -namely, 2 chief clerks, several clerks of lower classes, and a scientific staff of 3 professors, 4 junior professors, and I bibliographer, and a large number of civilian observers, printers, messengers, artisans, \&c.-at various points throughout the country. The number of civilian employés at the central or Washington office is 64 , all of whom give their whole timc to the work. The total of those employcd at other stations is apparently much greater than this; bul cach is employed only a short time daily, and most of them receive but 25 cents per day for some one special observation and record. The enlisted men of the service occupy about 200 stations scattered throughout the United States, including Alaska, at an average distance of 200 milcs apart. About an equal number of stations are also occupied by civilians, observing the height of water in the rivers, or displaying stormsignals. From about 4500 other civilian observers rcports are received gratuitously by mail on weekly or monthly forms. These observers are classified about as follows: voluntary land observers, 270; voluntary marine observers, 480; international observers, 330 ; Canadian observers, I8; state weather service, 450; tornado obscrvers, I200; thunderstorm reporters, 2000 .

The following are some of the more prominent and important steps of progress taken during General Hazen's administration :

The introduction of consulting specialists and civilian experts in the available working force of the office; the assignment of selccted sergeants and privates to work demanding a higher education and special aptness for investigation or study; the organised study of tornadoes, thunderstorms, atmospheric electricity, and other important novel fields of meteorological study; the introduction of weather-signals upon railroad-trains for the benefit of the farmers, and of local town-signals for the benefit of each community; the establishment of more severe rules for the verification of predictions, so that the 85 per cent. claimed at present means much more than it did a few years ago: the enlistment of a higher grade of men, the improvement of the courses of instruction for men and officers, the compilation of a working index to the literature of meteorology and the signal-office library, the organisation of new divisions in the office, especially of the study-room, the physical laboratory, the marine division, and the examiner's division ; the publication of a monthly summary of international simultaneous observation, with a weather-chart showing especially the storms on the Atlantic and Pacific Oceans that affect the United States; the special study of atmospheric moisture with a view to improved methods of determining this factor ; the special study of the exposure of thermometers, and correct methods for determining the temperature of the air; the maintenance of two polar and several auxiliary stations in pursuance of an international system for the study of the meteorology of the Polar regions : the adoption of many of the recommendations of the European International Meteorological Congresses looking to uniformity of methods throughout the world ; the adoption of improved methods of reducing barometric observations to sea-level; the stimulus given to the formation of State Weather Services (this great advance has been wholly due to Gen. Hazen, who has not hesitated to declare himself in favour of co-operation, and not monopoly; by his circulars and assistance over fifteen States have been led to develop minute internal systems for the study of local climate and the dissemination of weather-predictions); the stimulus given to higher scientific work by members of the Signal Service, by requiring and publishing professional papers, signal-notes, 'treatises, \&c. ; the addition to the Signal Office of a few experts in scientific matters, who are responsible for the proper conduct of work requiring special study; the establishment of a high class of standard instruments, and more exact methods for testing-apparatus furnished to the stations, thus assuring against any deterioration in the accuracy of the work through many years to come; the encouragement and co-operation in scientific work, bearing on meteorology, by outsidc parties, such as spectroscopy, the study of solar heat and atmospheric absorption, and the prosecution of balloon-voyares; the adoption of a uniform standard of time for all observers; the adoption of a uniform standard of gravity for barometric reductions; the introduction of new special cautionary signals for high north-west winds and cold waves; the extension of signal-service stations in Alaska for the proper study of storms that strike the Pacific coast, and are followed by the severe cold waves from Manitoba.

In the prosecution of these and other multifarious labours the signal-service certainly demands a high degree of organisation, discipline, and intelligence ; and it is by no means clear that this can be obtained in any better way than by a proper combination of military and civilian observers and scientific men. 